\title{
Regio- and Stereoselective Synthesis of Carbocyclic 2',3'-Dideoxy-3'-fluoro Nucleosides as Potential Antiviral Agents
}

\author{
Toshiaki Nakayama, ${ }^{a}$ Yasushi Matsumura, ${ }^{a}$ Yoshitomi Morizawa, ${ }^{*, a}$ Arata Yasuda, ${ }^{a}$ \\ Keiichi Uchida, ${ }^{a}$ Hiroyuki TaKase, ${ }^{b}$ Yoichi MuraKami, ${ }^{b}$ Shohgo Atarashi, ${ }^{b}$ \\ Tohru IKeUCHI, ${ }^{b}$ and Yasuaki OsADA ${ }^{b}$
}

Research Center, Asahi Glass Co., Ltd., ${ }^{a}$ Hazawa, Kanagawa-ku, Yokohama 221, Japan and Exploratory Research Laboratories I, Daiichi Pharmaceutical Co., Ltd.," 16-13, Kita-Kasai 1-chome, Edogawa-ku, Tokyo 134, Japan. Received April 16, 1993; accepted September 17, 1993

The synthesis and antiviral activity of racemic carbocyclic $2^{\prime}, 3^{\prime}$-dideoxy-3'-fluoro nucleosides are reported. Carbocyclic $2^{\prime}, 3^{\prime}$-dideoxy-3'-fluoro nucleosides were obtained from the 3-fluoro cyclopentane derivative 4 , which

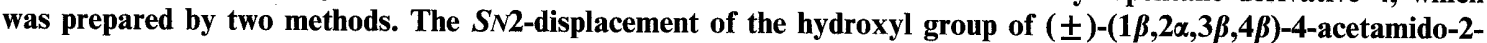
fluoro-3-hydroxycyclopentylmethyl acetate (1) with $\mathrm{Ph}_{3} \mathrm{P}-\mathrm{I}_{2}$ followed by tin hydride reduction afforded the 3-fluoroamino alcohol derivative 3. Alternatively, the protected fluoroamino alcohol 3 was prepared by regio- and stereoselective bromo-fluorination of $c i s-4 \beta$-acetamidocyclopent-2-enemethyl acetate (5) with hydrogen fluoridepyridine/ $N$-bromosuccinimide followed by tin hydride reduction to remove the bromine atom. Carbocyclic $2^{\prime}, 3^{\prime}$ dideoxy-3'-fluoroguanosine (14) thus obtained was moderately active against herpes simplex virus in vitro.

Keywords bromo-fluorination; carbocyclic nucleoside; fluoronucleoside; tin hydride reduction; antiviral agent; herpes simplex virus

Nucleoside analogues have been extensively investigated in the search for effective antiviral agents. There has been considerable interest in carbocyclic nucleosides, since the replacement of the oxygen atom of the furanose ring with methylene is a drastic change in terms of stereoelectronic effect on the nucleoside molecule and greater metabolic stability. ${ }^{1)}$ Much effort has been made to synthesize carbocyclic nucleoside analogues and also to modify the cyclopentane ring by introduction of an electronegative fluorine substituent. ${ }^{2)}$ The synthesis of a carbocyclic analogue of $3^{\prime}$-deoxy-3'-fluorothymidine was an important target, since it is the most potent anti-human immunodeficiency virus (anti-HIV) agent among fluorinated nucleosides so far synthesized. ${ }^{3)}$ However, only a limited amount of work has been done on the synthesis of $2^{\prime}, 3^{\prime}$-dideoxy-3'-fluoro analogues. ${ }^{4)}$

Independently, we have studied the stereo- and regioselective introduction of a fluorine atom onto a carbocyclic sugar moiety. In this report, we describe the synthesis of $2^{\prime}, 3^{\prime}$-dideoxy-3'-fluorocarbocyclic nucleosides using two methods, and we report on the antiviral activity of the products. ${ }^{5)}$

Chemistry For the synthesis of $3^{\prime}$-fluoro carbocyclic nucleoside analogues, we required the fluorocyclopentylamine (4) (Chart 1). The successful introduction of a fluorine atom into the carbocyclic ring by stereoselective epoxidation of $c i s-4 \beta$-acetamidocyclopent-2-enemethyl acetate $(5)^{6}$ followed by regioselective ring opening with hydrogen fluoride-pyridine to give the protected fluoro alcohol (1) with required stereochemistry has been described in an earlier report. ${ }^{5}$ However, reduction of the phenylthionocarbonate ${ }^{7)}$ of the $2^{\prime}$-hydroxyl group with tin hydride gave a complex mixture. After several attempts, replacement of the hydroxyl group by hydrogen atom to afford 3 was achieved by the substitution of the hydroxyl group with iodide using $\mathrm{Ph}_{3} \mathrm{P}-\mathrm{I}_{2}$ to give the cis-fluoro

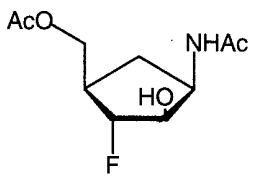

1

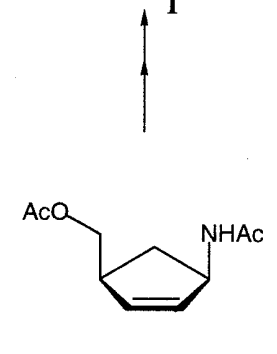

5

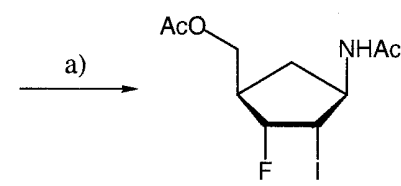

2
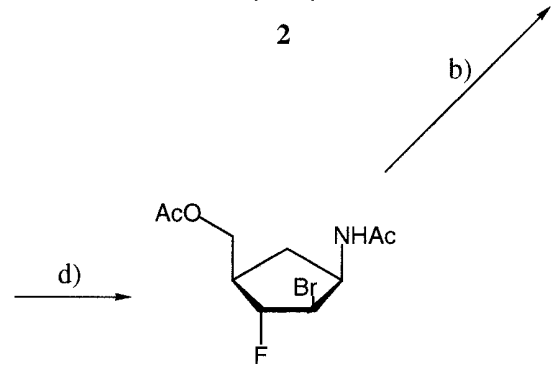

6

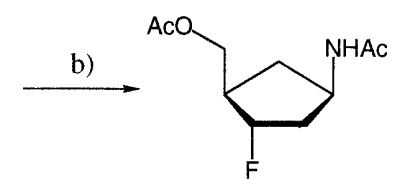

3

c)

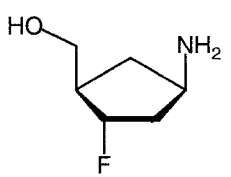

4

a) $\mathrm{Ph}_{3} \mathrm{P}-\mathrm{I}_{2}$, b) $\mathrm{Bu} \mathrm{u}_{3} \mathrm{SnH}, \mathrm{AIBN}$, c) $2 \mathrm{~N} \mathrm{HCl}$, d) $\mathrm{HF}-\mathrm{Py} / \mathrm{NBS}$

Chart 1 
iodide (2) in poor yield, followed by reduction with $\mathrm{Bu}_{3} \mathrm{SnH} /$ azobisisobutyronitrile (AIBN). ${ }^{9,10}$ )

A different stereochemistry of the leaving group adjacent to the fluorine atom might be expected to improve the overall yield in the synthesis of the fluorinated deoxycarbocyclic sugar moiety, since the electronic effect of the fluorine atom is expected to affect the substitution reaction. To explore this possibility, we examined bromofluorination $^{11)}$ of $c i s-4 \beta$-acetamidocyclopent-2-enemethyl acetate (5) to give the trans-bromo-fluoride. Bromofluorination of 5 with hydrogen fluoride-pyridine $/ N$ bromosuccinimide was regio- and stereoselective due to the syn-directing allylic amide group, ${ }^{6}$ giving the expected trans-fluoro amide (6) and the rearranged fluoroacetate (7) in the ratio of 74:26 (65\% yield) in tetrahydrofuran as a solvent. When the reaction was carried out in ether as a less polar solvent, the desired transfluoro amide was obtained exclusively in $77 \%$ yield. As expected, the bromine atom was smoothly reduced with $\mathrm{Bu}_{3} \mathrm{SnH} / \mathrm{AIBN}$ to provide 3 in $88 \%$ yield. Finally, deprotection of the acetyl group gave the fluorinated carbocyclic sugar moiety (4) in good yield.

The synthetic routes (Chart 2) to the fluorinated uridine, thymidine and cytidine analogues (8-10) from the fluorocyclopentylamine (4) were based on Shealy and O'dell's procedure. ${ }^{12)}$ Treatment of 4 with 3-ethoxyacryloyl isocyanate in $N, N$-dimethylformamide at $0{ }^{\circ} \mathrm{C}$ gave an intermediate acryloylurea, which was cyclized under reflux in $2 \mathrm{~N}$ hydrochloric acid to afford the fluorinated<smiles>CN1CC2[CH]C(OC(=O)[O-])C(C2)C1</smiles>

7<smiles>Nc1ccn(C2CCC(CO)C(F)C2)c(=O)n1</smiles>

a) $\mathrm{EtOCH}=\mathrm{CHCONCO}$

b) $\mathrm{H}^{+}$

c) $\mathrm{EtOCH}=\mathrm{C}(\mathrm{Me}) \mathrm{CONCO}$

d) $\mathrm{Ac}_{2} \mathrm{O}$, DMAP

e) mesitylenesulfonyl chloride, $\mathrm{Et}_{3} \mathrm{~N}$

f) sat. $\mathrm{NH}_{3}-\mathrm{MeOH}$

Chart 2<smiles></smiles>

13

a) 5-amino-4,6-dichloropyrimidine, b) $\mathrm{HC}(\mathrm{OEt})_{3}, \mathrm{H}^{+}$,

c) aq. $\mathrm{NH}_{3}$, d) 2-amino-4,6-dichloropyrimidine,

e) $p$-chlorobenzene diazonium chloride, then $\mathrm{Zn}-\mathrm{AcOH}$, f) $2 \mathrm{~N} \mathrm{HCl}$

Chart 3 
TABLE I. Antiviral and Anticellular Activity of Carbocyclic 2',3'-Dideoxy-3'-fluoro Nucleosides

\begin{tabular}{|c|c|c|c|c|c|c|c|}
\hline \multirow{2}{*}{ Compound } & \multicolumn{4}{|c|}{ Inhibition $\%$ of cytopathic effect of viruses at $20 \mu \mathrm{g} / \mathrm{ml} \mathrm{dose}^{a)}$} & \multicolumn{3}{|c|}{ Inhibition $\%$ of cytotoxicity at $100 \mu \mathrm{g} / \mathrm{ml}$ dose ${ }^{a)}$} \\
\hline & HSV-1 (KOS) $)^{b}$ & Influenza A & Adeno 3 & VSV & Vero & MDCK & $\mathrm{HeLa} \mathrm{S}_{3}$ \\
\hline 8 & $<10$ & $<10$ & $<10$ & $<10$ & $10-25$ & $<10$ & $<10$ \\
\hline 9 & $<10$ & $<10$ & $<10$ & $<10$ & $26-50$ & $10-25$ & $26-50$ \\
\hline 10 & $<10$ & $<10$ & $<10$ & $<10$ & $10-25$ & $<10$ & $10-25$ \\
\hline 12 & $<10$ & $<10$ & $10-25$ & $<10$ & $26-50$ & $10-25$ & $10-25$ \\
\hline 14 & $75-100$ & $<10$ & $<10$ & $<10$ & $10-25$ & $<10$ & $<10$ \\
\hline
\end{tabular}

a) Determined by the assay method of Munoz et al. ${ }^{15)}$ using crystal violet for staining viable Vero (HSV-1), MDCK (influenza A), or HeLa S 3 (adeno 3 and VSV) cells or uninfected cells. b) The strain is given in parentheses.

uracil (8). The corresponding carbocyclic $3^{\prime} \alpha$-fluorothymidine (9) was prepared from 4 in a similar manner to that used for the synthesis of $\mathbf{8}$. The cytidine analogue was obtained from the fluorinated uridine (8) according to the reported procedure. ${ }^{13)}$

On the other hand, the amine (4) was condensed with 5-amino-4,6-dichloropyrimidine ${ }^{14)}$ and the resulting pyrimidine (11) was treated with triethyl orthoformate in the presence of concentrated hydrochloric acid to give the 6-chloropurine. Reaction of the 6-chloropurine with ammonia gave carbocyclic $2^{\prime}, 3^{\prime}$-dideoxy-3'-fluoroadenosine (12) as illustrated in Chart 3.

The amine (4) was coupled with 2-amino-4,6-dichloropyrimidine to afford the diamine (13). Reaction of 13 with $p$-chlorobenzene diazonium chloride followed by reduction of the intermediate diazo compound gave the triamine, which was cyclized with triethyl orthoformate and then treated with $2 \mathrm{~N}$ hydrochloric acid to afford the desired fluoroguanosine (14).

\section{Biological Results}

The carbocyclic 2',3'-dideoxy-3'-fluoro nucleosides 8 , $9,10,12$, and 14 prepared in this study were tested in vitro for activity against herpes simplex virus type 1 (HSV-1), influenza virus type A, adenovirus type 3 and vesicular stomatitis virus (VSV). The assay method of Munoz et $a l .{ }^{15)}$ using crystal violet for staining viable cells was used to evaluate the activity of these compounds against the cytopathic effect of the viruses. The potency of each compound was evaluated in terms of the efficacy against the viruses at the concentration of $20 \mu \mathrm{g} / \mathrm{ml}$. The cytotoxicity of each compound was also determined at the concentration of $100 \mu \mathrm{g} / \mathrm{ml}$. The results obtained are summarized in Table I.

Of the five carbocyclic nucleoside analogues tested, carbocyclic $2^{\prime}, 3^{\prime}$-dideoxy-3'-fluoroguanosine (14) showed a marked activity against HSV-1 at $20 \mu \mathrm{g} / \mathrm{ml}$, and carbocyclic $2^{\prime}, 3^{\prime}$-dideoxy-3'-fluoroadenosine (12) was slightly active against adenovirus type 3 , but the other compounds 8, 9, and 10 showed no activity against any virus at $20 \mu \mathrm{g} / \mathrm{ml}$. Compound $\mathbf{1 4}$ was slightly cytotoxic to Vero cells, but showed no cytotoxicity towards MDCK and $\mathrm{HeLa} \mathrm{S}_{3}$ cells.

The potency of carbocyclic 2', $3^{\prime}$-dideoxy-3'-fluoroguanosine (14) was further tested against herpes simplex virus type 1 and 2 (HSV-1, HSV-2), varicella zoster virus (VZV), and human cytomegalovirus (HCMV) in HEL cells by plaque reduction assays. The results are given in Table
TABLE II. Antiherpes and Anticellular Activity of Carbocyclic 2', $3^{\prime}-$ Dideoxy-3'-fluoroguanosine

\begin{tabular}{lrcc}
\hline & \multicolumn{3}{c}{$\mathrm{ID}_{50}{ }^{a)}(\mu \mathrm{g} / \mathrm{ml})$} \\
\cline { 2 - 4 } Virus or cell & $\mathbf{1 4}$ & Ara A & ACV \\
\hline HSV-1 (KOS) $\left.{ }^{b}\right)$ & 2.7 & 1.6 & 0.13 \\
HSV-2 (UW268) & 10.0 & 3.2 & 0.34 \\
VZV (CaQu) & 12.1 & 1.6 & 2.4 \\
HCMV (AD169) & 15.0 & 6.6 & 10.0 \\
HEL cells & $<15.0$ & $<6.6$ & 440 \\
\hline
\end{tabular}

a) Determined by plaque reduction assays in HEL cells or cell proliferation assays in uninfected cells. b) The strain is given in parentheses.

II. Adenine arabinoside (Ara-A) and acyclovir (ACV) were used as positive controls in this experiment.

Compound 14 was the most active against HSV-1, with ID $_{50}$ values of $2.7 \mu \mathrm{g} / \mathrm{ml}$, but was less active against HSV-2, VZV and HCMV, with ID $_{50}$ values of $10.0,12.1$ and $15.0 \mu \mathrm{g} / \mathrm{ml}$, respectively. The activity against HSV-1 was similar to that of Ara-A, but about 10 times less than that of ACV. The cytotoxicity of $\mathbf{1 4}$ towards HEL cells was quite high $(<15.0 \mu \mathrm{g} / \mathrm{ml})$, and was comparable to that of Ara-A.

\section{Experimental}

${ }^{1} \mathrm{H}$-NMR and ${ }^{19} \mathrm{~F}-\mathrm{NMR}$ spectra were taken on a JEOL JNM-FX-90Q spectrometer. References were tetramethylsilane for ${ }^{1} \mathrm{H}$ spectra and $\mathrm{CFCl}_{3}$ for ${ }^{19} \mathrm{~F}$ spectra. All chemical shifts were recorded downfield from the references. IR spectra were measured on a JASCO IR-810 spectrophotometer. High-resolution mass spectra (high-resolution MS) were recorded on a JEOL SX-102A mass spectrometer. Products were purified by column chromatography on silica gel (Merck, 0.063$0.200 \mathrm{~mm}$ or $0.040-0.063 \mathrm{~mm}$ ).

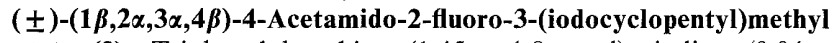
Acetate (2) Triphenylphosphine $(1.45 \mathrm{~g}, 1.8 \mathrm{mmol})$, iodine $(0.94 \mathrm{~g}$, $3.7 \mathrm{mmol})$ and imidazole $(0.36 \mathrm{~g}, 5.5 \mathrm{mmol})$ were added to a solution of $( \pm)-(1 \beta, 2 \alpha, 3 \beta, 4 \beta)$-4-acetamido-2-fluoro-3-(hydroxycyclopentyl)methyl acetate $(\mathbf{1})(0.43 \mathrm{~g}, 1.6 \mathrm{mmol})$ in toluene $(37 \mathrm{ml})$, and the mixture was heated under reflux. After $4 \mathrm{~h}$, the mixture was poured into saturated aqueous sodium hydrogen carbonate solution and extracted with chloroform. The combined extracts, dried with magnesium sulfate, were evaporated to dryness in vacuo. Purification by column chromatography gave 2 (oil, $55 \mathrm{mg}, 9 \%$ yield). ${ }^{1} \mathrm{H}-\mathrm{NMR}\left(\mathrm{CDCl}_{3}\right) \delta: 1.20-2.60(3 \mathrm{H}, \mathrm{m})$, $1.93(3 \mathrm{H}, \mathrm{s}), 2.03(3 \mathrm{H}, \mathrm{s}), 4.00-5.50(5 \mathrm{H}, \mathrm{m}) .{ }^{19} \mathrm{~F}-\mathrm{NMR}\left(\mathrm{CDCl}_{3}\right)$ : $-166.0 \mathrm{ppm}$ (ddd, $J=51.8,27.3,6.6 \mathrm{~Hz}$ ).

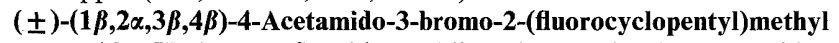
Acetate (6) Hydrogen fluoride-pyridine $(70 \%)(1 \mathrm{ml})$ was added dropwise to a solution of $\mathrm{N}$-bromosuccinimide $(218 \mathrm{mg}, 1.2 \mathrm{mmol}$ ) in ether $(1 \mathrm{ml})$ at $0^{\circ} \mathrm{C}$, and then a solution of $c i s-4 \beta$-acetamidocyclopentenemethyl acetate (5) $(243 \mathrm{mg}, 1.2 \mathrm{mmol})$ in ether $(1 \mathrm{ml})$ was further added dropwise at $0^{\circ} \mathrm{C}$. The mixture was stirred at the same temperature for $30 \mathrm{~min}$ and at room temperature for $2 \mathrm{~h}$, then poured into saturated 
aqueous sodium hydrogen carbonate solution and extracted with chloroform. The combined extracts were dried with magnesium sulfate, and evaporated to dryness in vacuo. Purification by column chromatography (chloroform: methanol $=50: 1$ ) gave 6 (oil, $280 \mathrm{mg}$, $77 \%$ yield). ${ }^{1} \mathrm{H}-\mathrm{NMR}\left(\mathrm{CDCl}_{3}\right) \delta: 1.3-2.8(3 \mathrm{H}, \mathrm{m}), 2.03(3 \mathrm{H}, \mathrm{s}), 2.09$ $(3 \mathrm{H}, \mathrm{s}), 4.2-5.5(5 \mathrm{H}, \mathrm{m}), 5.9(1 \mathrm{H}, \mathrm{br} \mathrm{s}) .{ }^{19} \mathrm{~F}-\mathrm{NMR}\left(\mathrm{CDCl}_{3}\right):-154.0 \mathrm{ppm}$ (ddd, $J=49.6,13.9,14.7 \mathrm{~Hz}$ ). IR $\left(\mathrm{CDCl}_{3}\right): 3040,1750,1520 \mathrm{~cm}^{-1}$.

When the reaction was carried out in tetrahydrofuran, 6 was obtained in $48 \%$ yield accompanied with the rearranged product (7) in $17 \%$ yield. ${ }^{16)} 7:{ }^{1} \mathrm{H}-\mathrm{NMR}\left(\mathrm{CDCl}_{3}\right) \delta: 1.5-1.8(3 \mathrm{H}, \mathrm{m}), 2.03(3 \mathrm{H}, \mathrm{s}), 2.08$ $(3 \mathrm{H}, \mathrm{s}), 3.4-3.7(2 \mathrm{H}, \mathrm{m}), 3.9-4.9(3 \mathrm{H}, \mathrm{m}), 5.9-6.1(1 \mathrm{H}, \mathrm{m}) .{ }^{19} \mathrm{~F}-\mathrm{NMR}$ $\left(\mathrm{CDCl}_{3}\right):-218.5 \mathrm{ppm}$ (ddd, $J=47.4,28.1,11.0 \mathrm{~Hz}$ )

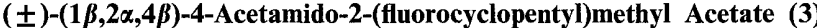
Method A (from Iodide 2): $\alpha, \alpha^{\prime}$-AIBN ( $1 \mathrm{mg}$ ) and tributyltin hydride $(0.23 \mathrm{ml}, 0.85 \mathrm{mmol})$ were added to a solution of $2(55 \mathrm{mg}, 0.16 \mathrm{mmol})$ in benzene $(1 \mathrm{ml})$. The solution was refluxed for $20 \mathrm{~min}$ and all the volatile materials were evaporated off under reduced pressure. The residue was purified on a silica gel column to give 3 (powder, $36 \mathrm{mg}, 100 \%$ yield). ${ }^{1} \mathrm{H}-\mathrm{NMR}\left(\mathrm{CDCl}_{3}\right) \delta: 1.00-2.60(5 \mathrm{H}, \mathrm{m}), 1.96(3 \mathrm{H}, \mathrm{s}), 2.08(3 \mathrm{H}, \mathrm{s})$ $4.00-5.40(4 \mathrm{H}, \mathrm{m}), 5.90(1 \mathrm{H}, \mathrm{br}) .{ }^{19} \mathrm{~F}-\mathrm{NMR}\left(\mathrm{CDCl}_{3}\right):-171.1 \mathrm{ppm}$ (dddd, $J=52.7,33.2,28.6,21.7 \mathrm{~Hz})$. IR $\left(\mathrm{CHCl}_{3}\right): 1743,1680,1520$ $\mathrm{cm}^{-1}$

Method B (from Bromide 6): $\alpha, \alpha^{\prime}$-AIBN (5mg) and tributyltin hydride $(1.25 \mathrm{ml}, 4.6 \mathrm{mmol})$ were added to a solution of $6(178 \mathrm{mg}$, $0.94 \mathrm{mmol}$ ) in benzene $(20 \mathrm{ml})$ and the solution was refluxed for $10 \mathrm{~min}$ All the volatile materials were removed in vacuo and the residue was purified by silica gel column chromatography to give 3 (169 mg, $88 \%$ yield).

( \pm$)-(1 \beta, 2 \alpha, 4 \beta)-4-A m i n o-2-f l u o r o c y c l o p e n t a n e m e t h a n o l ~(4)^{4 a)}$ A suspension of $3(169 \mathrm{mg}, 0.78 \mathrm{mmol})$ in $2 \mathrm{~N}$ hydrochloric acid $(4 \mathrm{ml})$ was heated under reflux for $8 \mathrm{~h}$. Purification with Diaion SA-11A gave 4 (oil, $103 \mathrm{mg}, 100 \%$ yield). ${ }^{1} \mathrm{H}-\mathrm{NMR}\left(\mathrm{D}_{2} \mathrm{O}\right) \delta: 0.80-2.40(5 \mathrm{H}, \mathrm{m}), 3.40-5.20$ $(4 \mathrm{H}, \mathrm{m}) .{ }^{19} \mathrm{~F}-\mathrm{NMR}\left(\mathrm{D}_{2} \mathrm{O}\right):-165.1 \mathrm{ppm}$ (dddd, $J=54.0,36.6,31.3$, $22.7 \mathrm{~Hz})$.

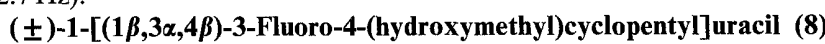
3-Ethoxy-2-propenoyl isocyanate $(0.4 \mathrm{M}$ benzene solution, $2.5 \mathrm{ml}, 1.0$ mmol) was added to a solution of $4(130 \mathrm{mg}, 0.98 \mathrm{mmol})$ in $N, N$ dimethylformamide $(5 \mathrm{ml})$ at $0^{\circ} \mathrm{C}$ over a period of $5 \mathrm{~min}$. After $10 \mathrm{~min}$, all the volatiles were evaporated off under reduced pressure at $30^{\circ} \mathrm{C}$. The residue was taken up in $2 \mathrm{~N}$ hydrochloric acid $(10 \mathrm{ml})$ and heated under reflux for $20 \mathrm{~min}$. After cooling to $0^{\circ} \mathrm{C}$, the solution was neutralized with $2 \mathrm{~N}$ sodium hydroxide and the solvent was evaporated off. Purification by silica gel column chromatography afforded 8 (fine powder, $150 \mathrm{mg}, 67 \%$ yield). ${ }^{1} \mathrm{H}-\mathrm{NMR}\left(\mathrm{D}_{2} \mathrm{O}\right) \delta: 1.6-3.0(5 \mathrm{H}, \mathrm{m})$ $3.8-4.0(2 \mathrm{H}, \mathrm{m}), 4.9-5.8(2 \mathrm{H}, \mathrm{m}), 6.10(1 \mathrm{H}, \mathrm{d}, J=7.9 \mathrm{~Hz}), 8.00(1 \mathrm{H}$, $\mathrm{d}, J=7.9 \mathrm{~Hz}) .{ }^{19} \mathrm{~F}-\mathrm{NMR}\left(\mathrm{D}_{2} \mathrm{O}\right):-159.2(\mathrm{~m})$. High-resolution MS (FAB) $m / z$ : Calcd for $\mathrm{C}_{10} \mathrm{H}_{13} \mathrm{FN}_{2} \mathrm{O}_{3}: 229.0989$. Found: 229.0995. Anal. Calcd for $\mathrm{C}_{10} \mathrm{H}_{13} \mathrm{FN}_{2} \mathrm{O}_{3}$ : C, 52.63; H, 5.74; N, 12.27. Found: C, 52.33; H, $5.75 ; \mathrm{N}, 12.47$

( \pm )-1-[(1 $\beta, 3 \alpha, 4 \beta)-3-F l u o r o-4-(h y d r o x y m e t h y l) c y c l o p e n t y l]$ thymine (9) ${ }^{4)}$ 3-Ethoxy-2-methyl-2-propenoyl isocyanate $(0.4 \mathrm{M}$ benzene solution, $3.8 \mathrm{ml}, 1.5 \mathrm{mmol})$ was added to a solution of $4(200 \mathrm{mg}, 1.5 \mathrm{mmol})$ in $N, N$-dimethylformamide $(7 \mathrm{ml})$ at $0^{\circ} \mathrm{C}$ over a period of $5 \mathrm{~min}$. After $10 \mathrm{~min}$, all the volatiles were evaporated off under reduced pressure at $30^{\circ} \mathrm{C}$ and $2 \mathrm{~N}$ hydrochloric acid $(10 \mathrm{ml})$ was added. The solution was heated under reflux for $20 \mathrm{~min}$, then cooled to $0^{\circ} \mathrm{C}$, and neutralized with $2 \mathrm{~N}$ sodium hydroxide. The solution was evaporated to dryness and purified by silica gel column chromatography to give 9 (powder, $350 \mathrm{mg}$, $96 \%$ yield). ${ }^{1} \mathrm{H}-\mathrm{NMR}$ (acetone- $\left.d_{6}\right) \delta: 1.6-2.7(8 \mathrm{H}, \mathrm{m}+\mathrm{s}(\delta 1.88))$, $3.0-5.6(4 \mathrm{H}, \mathrm{m}), 7.68(1 \mathrm{H}, \mathrm{br} \mathrm{s}) .{ }^{19} \mathrm{~F}-\mathrm{NMR}$ (acetone- $\left.d_{6}\right):-165.2 \mathrm{ppm}$ (m). High-resolution MS (FAB) $m / z$ : Calcd for $\mathrm{C}_{11} \mathrm{H}_{15} \mathrm{FN}_{2} \mathrm{O}_{3}: 243.1145$ Found: 243.1151. Anal. Calcd for $\mathrm{C}_{11} \mathrm{H}_{15} \mathrm{FN}_{2} \mathrm{O}_{3}$ : C, 54.54; $\mathrm{H}, 6.24 ; \mathrm{N}$, 11.56. Found: C, $54.54 ; \mathrm{H}, 6.02 ; \mathrm{N}, 11.43$.

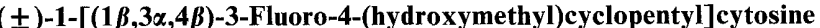
(10) 4-Dimethylaminopyridine $(10 \mathrm{mg}, 0.08 \mathrm{mmol})$ and acetic anhydride $(1 \mathrm{ml})$ were added to a solution of $8(240 \mathrm{mg}, 1.0 \mathrm{mmol})$ in pyridine $(10 \mathrm{ml})$, and the mixture was stirred at room temperature for $30 \mathrm{~min}$. The solution was poured into $0.5 \mathrm{M}$ potassium dihydrogen phosphate solution $(50 \mathrm{ml})$ and extracted with ethyl acetate $(50 \mathrm{ml})$. The organic layer was dried over magnesium sulfate and concentrated. The residue was dissolved in acetonitrile $(10 \mathrm{ml})$, and 2-mesitylenesulfonyl chloride $(670 \mathrm{mg}, 3.0 \mathrm{mmol})$ and triethylamine $(0.42 \mathrm{ml}, 3.0 \mathrm{mmol})$ were added to the solution at room temperature. The whole was stirred for $50 \mathrm{~min}$, then evaporated to dryness, and saturated ammonia-methanol $(3 \mathrm{ml})$ was added to the residue at room temperature. After $15 \mathrm{~h}$, the solution was evaporated and $50 \%$ methanol-water $(20 \mathrm{ml})$ was added to the residue. The solution was applied to an Amberlite CG-120 ( $\mathrm{H}^{+}$form) column, which was washed with water, and then eluted with $5 \%$ ammonium hydroxide to give 10 (powder, $55 \mathrm{mg}, 24 \%$ yield). ${ }^{1} \mathrm{H}$-NMR $\left(\mathrm{CD}_{3} \mathrm{OD}\right) \delta: 1.64-2.78(5 \mathrm{H}, \mathrm{m}), 3.83(2 \mathrm{H}$, brd $), 5.26(1 \mathrm{H}, \mathrm{dm}$, $J=53.22 \mathrm{~Hz}), 5.38(1 \mathrm{H}, \mathrm{m}), 6.13(1 \mathrm{H}, \mathrm{d}, J=7.5 \mathrm{~Hz}), 7.95(1 \mathrm{H}, \mathrm{d}$, $J=7.5 \mathrm{~Hz}) .{ }^{19} \mathrm{~F}-\mathrm{NMR}\left(\mathrm{CD}_{3} \mathrm{OD}\right):-167.5 \mathrm{ppm}(\mathrm{ddt}, J=22.95,30.76$, $53.22 \mathrm{~Hz}$ ). Anal. Calcd for $\mathrm{C}_{10} \mathrm{H}_{14} \mathrm{FN}_{3} \mathrm{O}_{2} \cdot 0.5 \mathrm{H}_{2} \mathrm{O}: \mathrm{C}, 50.84 ; \mathrm{H}, 6.40$; $\mathrm{N}, 17.79$. Found: C, 50.59; H, 6.21; N, 17.65 .

( \pm )-9-[(1 $\beta, 3 \alpha, 4 \beta)-3$-Fluoro-4-(hydroxymethyl)cyclopentyl]-6-aminopurine (12) Method A (from Carbocyclic 3'-Deoxy-3'-fluoroadenosine $\left.^{5)}\right): N, N$-Dimethylformamide dimethylacetal $(2.03 \mathrm{ml}, 15.3 \mathrm{mmol})$ was added to a solution of carbocyclic $3^{\prime}$-deoxy- $3^{\prime}$-fluoroadenosine $(0.67 \mathrm{~g}, 2.7 \mathrm{mmol})$ in $N, N$-dimethylformamide $(12 \mathrm{ml})$, and the mixture was stirred for $2 \mathrm{~h}$ at room temperature. All the volatiles were evaporated off under reduced pressure and purification by silica gel column chromatography gave the 6-dimethylaminomethyleneiminopurine derivative $(0.68 \mathrm{~g}, 2.24 \mathrm{mmol}, 83 \%$ yield).

Imidazole $(0.233 \mathrm{~g}, 3.42 \mathrm{mmol})$ and tert-butyldimethylsilyl chloride $(0.258 \mathrm{~g}, 1.71 \mathrm{mmol})$ were added to a solution of the 6-dimethylaminomethyleneiminopurine derivative $(0.53 \mathrm{~g}, 1.71 \mathrm{mmol})$ in $N, N$-dimethylformamide $(3 \mathrm{ml})$ at $0{ }^{\circ} \mathrm{C}$. The mixture was stirred for $10 \mathrm{~h}$ at room temperature, and usual work-up gave $5^{\prime}$-O-tert-butyldimethylsilyl protected carbocyclic fluoroadenosine (gum, $264 \mathrm{mg}, 0.63 \mathrm{mmol}, 37 \%$ yield) and the starting diol $(250 \mathrm{mg}, 0.82 \mathrm{mmol}, 48 \%$ yield $) .{ }^{1} \mathrm{H}-\mathrm{NMR}$ $\left(\mathrm{CDCl}_{3}\right) \delta: 0.00(6 \mathrm{H}, \mathrm{s}), 0.88(9 \mathrm{H}, \mathrm{s}), 3.19(3 \mathrm{H}, \mathrm{s}), 3.24(3 \mathrm{H}, \mathrm{s}), 3.40-5.31$ $(7 \mathrm{H}, \mathrm{m}), 7.96(3 \mathrm{H}, \mathrm{s}), 8.67(1 \mathrm{H}, \mathrm{s}), 9.07(1 \mathrm{H}, \mathrm{s}) .{ }^{19} \mathrm{~F}-\mathrm{NMR}\left(\mathrm{CDCl}_{3}\right)$ : $-191.3 \mathrm{ppm}$ (ddd, $J=25.7,32.6,56.5 \mathrm{~Hz}$ ).

The above compound $(230 \mathrm{mg}, 0.52 \mathrm{mmol})$ in dichloromethane $(5 \mathrm{ml})$ was allowed to react with phenylchlorothionocarbonate $(170 \mathrm{mg}$, $1.56 \mathrm{mmol}$ ). The mixture was stirred for $15 \mathrm{~min}$ at room temperature, and usual work-up followed by reduction with tributyltin hydride $(1.0 \mathrm{~g}$, $3.45 \mathrm{mmol}$ ) in the presence of $\alpha, \alpha^{\prime}$-azobisisobutyronitrile $(5 \mathrm{mg})$ gave the deoxy derivative. Deprotection of the $5^{\prime}$-hydroxyl group with tetrabutylammonium fluoride and of the 6-amino group with $28 \%$ ammonium hydroxide gave carbocyclic $2^{\prime}, 3^{\prime}$-dideoxy-3'-fluoroadenosine (12) (powder, $90 \mathrm{mg}, 69 \%$ yield). ${ }^{1} \mathrm{H}-\mathrm{NMR}\left(\mathrm{D}_{2} \mathrm{O}\right) \delta: 1.6-2.0(5 \mathrm{H}, \mathrm{m})$, $3.75(2 \mathrm{H}, \mathrm{d}, J=5.4 \mathrm{~Hz}), 3.8-4.6(2 \mathrm{H}, \mathrm{m}), 7.19(1 \mathrm{H}, \mathrm{s}), 7.24(1 \mathrm{H}, \mathrm{s})$. ${ }^{19} \mathrm{~F}-\mathrm{NMR}\left(\mathrm{D}_{2} \mathrm{O}-\mathrm{CDCl}_{3}\right)$ : $-165.9 \mathrm{ppm}$ (dddd, $J=52.1,34.5,30.5$, $18.7 \mathrm{~Hz}$ ). High-resolution MS (FAB) $m / z$ : Calcd for $\mathrm{C}_{11} \mathrm{H}_{14} \mathrm{FN}_{5} \mathrm{O}$ : 252.1261. Found: 252.1253. Anal. Calcd for $\mathrm{C}_{11} \mathrm{H}_{14} \mathrm{FN}_{5} \mathrm{O} \cdot 2 \mathrm{H}_{2} \mathrm{O}: \mathrm{C}$, 45.99; H, 5.61; N, 24.38. Found: C, 46.02; H, 5.86; N, 24.46.

Method B (from Compound 4): Compound 12 was synthesized from 4 according to Dalge and Vince. ${ }^{6}$ The cyclopentylamine (4) was allowed to react with 5-amino-4,6-dichloropyrimidine in the presence of triethylamine, followed by ring construction with triethyl orthoformate and ammonolysis with saturated ammonia-methanol to give carbocyclic $2^{\prime}, 3^{\prime}$-dideoxy-3'-fluoroadenosine.

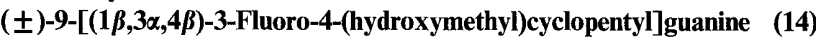
2-Amino-4,6-dichloropyrimidine $(2.49 \mathrm{~g}, 15.22 \mathrm{mmol})$ and triethylamine $(2.1 \mathrm{ml}, 15.2 \mathrm{mmol})$ were added to a solution of $4(910 \mathrm{mg}, 6.8 \mathrm{mmol})$ in 1 -butanol $(30 \mathrm{ml})$, and the mixture was heated under reflux for $15 \mathrm{~h}$. The solution was cooled to $0{ }^{\circ} \mathrm{C}$ and filtered, and the filtrate was evaporated to dryness to give 13. The residue was dissolved in acetic acid $(34 \mathrm{ml})-\mathrm{H}_{2} \mathrm{O}$ $(34 \mathrm{ml})$, and then sodium acetate trihydrate $(13.6 \mathrm{~g})$ and 4-chlorobenzenediazonium chloride solution $(16 \mathrm{ml}, 7.5 \mathrm{mmol})$ were added. The whole was stirred at $70^{\circ} \mathrm{C}$ for $1 \mathrm{~h}$, then the precipitate was collected and dried. To the residue, $50 \%$ ethanol- $\mathrm{H}_{2} \mathrm{O}(100 \mathrm{ml})$, acetic acid $(11 \mathrm{ml})$, and zinc powder $(11 \mathrm{~g})$ were successively added and the mixture was stirred at $70^{\circ} \mathrm{C}$ for $1 \mathrm{~h}$. After filtration, the solution was poured onto Amberlite $\mathrm{CG}-120\left(\mathrm{H}^{+}\right.$form), washed with water, and eluted with $5 \%$ ammonium hydroxide to give $(4 \alpha, 2 \beta, 1 \alpha)-4-(2,5$-diamino-6-chloro-4pyrimidinylamino)-2-fluorocyclopentanemethanol $(380 \mathrm{mg}, 20 \%$ yield). IR (film): $3300 \mathrm{~cm}^{-1}$.

Triethyl orthoformate $(30 \mathrm{ml})$ and concentrated hydrochloric acid $(1 \mathrm{ml})$ were added to a solution of this triaminopyrimidine $(190 \mathrm{mg}$, $0.69 \mathrm{mmol})$ in $N, N$-dimethylformamide $(20 \mathrm{ml})$, and the mixture was stirred for $48 \mathrm{~h}$. After evaporation of all the volatiles, $2 \mathrm{~N}$ hydrochloric acid $(20 \mathrm{ml})$ was added to the residue and the mixture was heated under reflux for $4 \mathrm{~h}$. The solution was applied to a column of Amberlite CG-120 $\left(\mathrm{H}^{+}\right.$form) and eluted with $5 \%$ ammonium hydroxide to give 14 (powder, $101 \mathrm{mg}, 55 \%$ yield). ${ }^{1} \mathrm{H}-\mathrm{NMR}\left(\mathrm{CD}_{3} \mathrm{OD}\right) \delta: 1.91-2.89(5 \mathrm{H}, \mathrm{m}), 3.87$ $(2 \mathrm{H}$, brd $), 5.02-5.68(2 \mathrm{H}, \mathrm{m}), 8.09(1 \mathrm{H}, \mathrm{s}) .{ }^{19} \mathrm{~F}-\mathrm{NMR}\left(\mathrm{CD}_{3} \mathrm{OD}\right)$; 
$-167.5 \mathrm{ppm}(\mathrm{m})$. High-resolution MS (FAB) $m / z$ : Calcd for $\mathrm{C}_{11} \mathrm{H}_{15^{-}}$ $\mathrm{FN}_{5} \mathrm{O}_{2}$ : 268.1210. Found: 268.1208. Anal. Calcd for $\mathrm{C}_{11} \mathrm{H}_{15} \mathrm{FN}_{5} \mathrm{O}_{2}$. $3.5 \mathrm{H}_{2} \mathrm{O}: \mathrm{C}, 39.88 ; \mathrm{H}, 6.69 ; \mathrm{N}, 21.13$. Found: $\mathrm{C}, 40.12 ; \mathrm{H}, 6.56 ; \mathrm{N}, 20.94$.

\section{References and Notes}

1) a) V. E. Marquez, M.-I. Lin, Med. Res. Rev., 6, 1 (1986); b) N. Katagiri, Yuki Gosei Kagaku Kyokaishi, 47, 707 (1989).

2) a) A. D. Borthwick, D. W. Evans, B. E. Kirk, K. Biggadike, A. M. Exall, P. Youds, S. M. Roberts, D. J. Knight, J. A. V. Coates, J. Med. Chem., 33, 179 (1990); b) A. D. Borthwick, K. Biggadike, S. Holman, C. Ho, Tetrahedron Lett., 31, 767 (1990); c) C. A. Fletcher, H. Hilpert, P. L. Myers, S. M. Roberts, R. Storer, J. Chem. Soc., Chem. Commun., 1989, 1707; d) D. M. Coe, H. Hilpert, S. A. Noble, M. R. Peel, S. M. Roberts, R. Storer, ibid., 1991, 312; e) K. Biggadike, A. D. Borthwick, ibid., 1990, 1380.

3) P. Herdewijn, J. Balzarini, E. De Clercq, R. Pauwels, M. Baba, S. Broder, H. Vanderhaeghe, J. Med. Chem., 30, 1270 (1987).

4) a) H. Baumgartner, M. Bodenterch, H. Griengl, Tetrahedron Lett., 29, 5745 (1988); b) J. Bares, G. Sagi, E. Baritz-Gacs, I. Tomoskozi, L. Gruber, L. Otvas, Tetrahedron, 45, 6271 (1989).

5) A preliminary account of part of this work has appeared: $T$. Nakayama, Y. Morizawa, Y. Matsumura, A. Yasuda, K. Uchida, Nucleic Acids Symp. Ser., 21, 73 (1989).
6) S. Daluge, R. Vince, J. Org. Chem., 43, 2311 (1978)

7) M. J. Robins, J. S. Wilson, J. Am. Chem. Soc., 103, 932 (1981).

8) J. P. H. Verheyden, J. G. Moffatt, J. Am. Chem. Soc., 86, 2093 (1964).

9) D. H. Barton, R. Subramanian, J. Chem. Soc., Perkin Trans. I, 1977, 1718.

10) On the other hand, the $2^{\prime}$-hydroxy group of carbocyclic $3^{\prime}$ deoxy-3'-fluoroadenosine was replaced by a hydrogen atom by the following procedure: selective protection of $6-\mathrm{NH}_{2}$ and $5^{\prime}-\mathrm{OH}$ group, transformation of 2 '-OH group to phenylthionocarbonate, reduction with $\mathrm{Bu}_{3} \mathrm{SnH} / \mathrm{AIBN}$, and deprotection in $21 \%$ overall yield (see Experimental).

11) G. A. Olah, M. Nojima, I. Korekes, Synthesis, 1973, 779

12) a) Y. F. Shealy, C. A. O'Dell, J. Heterocyclic Chem., 13, 1015 (1976); b) Idem, ibid., 13, 1041 (1976).

13) T. M. Jacob, H. G. Khorana, J. Am. Chem. Soc., 86, 1630 (1964).

14) Y. F. Shealy, J. O. Chaytonm, J. Pharm. Sci., 62, 1432 (1973).

15) A. Munoz, R. A. Garcia, A. Perez-Aranda, Antimicrob. Agents Chemother., 30, 192 (1986).

16) The unprecedented rearrangement might proceed via migration of the C-5 acetoxyl group to $\mathrm{C}-3$, activated by bromonium ion, followed by the attack of fluorine atom at C-5. 